
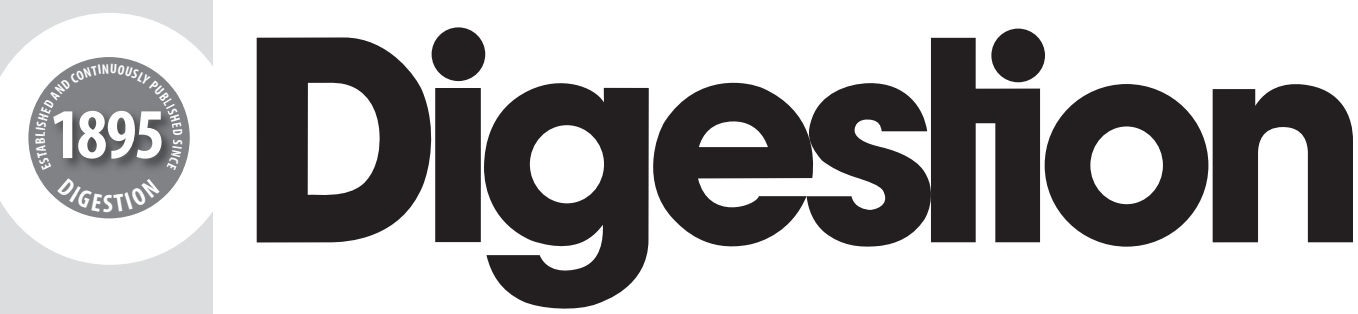

\title{
International Journal of Gastroenterology
}

Founded as 'Archiv für Verdauungskrankheiten' 1895 by I. Boas

Continued as 'Gastroenterologia' 1939-1967

Former Editors: P. Morawitz (1934-1936), R. Staehelin (1937-1943), A. Hurst (1940-1945),

W. Löffler (1943-1961), T.C. Hunt (1947-1967), N. Henning (1953-1962), B. Ihre (1953-1967),

H. Bartelheimer (1963-1967), M. Demole (1963-1971), H. Kapp (1968-1970),

R. Lambert (1972-1978), W. Creutzfeldt (1979-1992), R. Arnold (1993-2003),

C. Beglinger (2004-2011)

\section{Editors-in-Chief}

B. Göke, Munich

Y. Shinomura, Sapporo

\section{Managing Editors}

F. Kolligs, Munich

C. Rust, Munich

\section{Associate Editors}
A. Andoh, Otsu
A. Canbay, Essen
V. Ellenrieder, Marburg
W. Fischbach, Aschaffenburg
E. Gallmeier, Munich
K. Higuchi, Osaka
G. Holtmann, Brisbane, Qld.
R. Jakobs, Ludwigshafen
Y. Kinoshita, Izumo
A. Nakajima, Yokohama
G. Rogler, Zurich
Y. Sasaki, Kumamoto
T. Takayama, Tokushima
K. Takeuchi, Kyoto
M. Tanaka, Fukuoka

Official Journal of

The Japanese

Gastroenterological

Association (JGA)

\section{JGA Editorial Representatives}

Y. Kinoshita, Izumo

K. Higuchi, Osaka 
S. Karger

Medical and Scientific Publishers

Basel $•$ Freiburg $•$ Paris $•$ London •

New York • Chennai • New Delhi

Bangkok $\cdot$ Beijing $\cdot$ Shanghai $\cdot$ Tokyo

Kuala Lumpur $\cdot$ Singapore $\cdot$ Sydney
Disclaimer

The statements, opinions and data contained in this publication are solely those of the individual authors and contributors and not of the publisher and the editor(s). The appearance of advertisements in the journal is not a warranty, endorsement, or approval of the products or services advertised or of their effectiveness, quality or safety. The publisher and the editor(s) disclaim responsibility for any injury to persons or property resulting from any ideas, methods, instructions or products referred to in the content or advertisements.

Drug Dosage

The authors and the publisher have exerted every effort to ensure that drug selection and dosage set forth in this text are in accord with current recommendations and practice at the time of publication. However, in view of ongoing research, changes in government regulations, and the constant flow of information relating to drug therapy and drug reactions, the reader is urged to check the package insert for each drug for any change in indications and dosage and for added warnings and precautions. This is particularly important when the recommended agent is a new and/or infrequently employed drug.
All rights reserved.

No part of this publication may be translated into other languages, reproduced or utilized in any form or by any means electronic or mechanical, including photocopying, recording microcopying, or by any information storage and retrieval system, without permission in writing from the publisher or in the case of photocopying, direct payment of a specified fee to the Copyright Clearance Center (see 'General Information').

(c) Copyright 2013 by S. Karger AG

CH-4009 Basel (Switzerland)

Printed on acid-free and non-aging paper (ISO 9706)

\section{KARGER}


No. 1

JGA Topic Review

17 Mechanism and Therapeutic Strategy of Secondary Failure to Anti-Tumor Necrosis Factor-a Monoclonal Antibody Treatment for Crohn's Disease

Matsuoka, Y.; Kanai, T. (Tokyo)

Review

33 Meta-Analysis of Bismuth Quadruple Therapy versus Clarithromycin Triple Therapy for Empiric Primary Treatment of Helicobacter pylori Infection

Venerito, M. (Magdeburg); Krieger, T.; Ecker, T. (Hamburg); Leandro, G. (Castellana Grotte); Malfertheiner, P. (Magdeburg)

Original Papers

1 Frequency and Phenotype of Human Circulating and Intrahepatic Natural Killer Cell Subsets Is Differentially Regulated according to Stage of Chronic Liver Disease Zimmermann, H.W.; Mueller, J.R.; Seidler, S.; Luedde, T.; Trautwein, C.; Tacke, F. (Aachen)

20 Racial/Ethnic and Regional Differences in the Prevalence of Inflammatory Bowel Disease in the United States

Wang, Y.R. (Jacksonville, Fla./Philadelphia, Pa.); Loftus Jr., E.V. (Rochester, Minn.); Cangemi, J.R.; Picco, M.F. (Jacksonville, Fla.)

26 Severe and Morbid Obesity in Crohn's Disease Patients: Prevalence and Disease Associations

Ungar, B.; Kopylov, U.; Goitein, D.; Lahat, A.; Bardan, E.; Avidan, B.; Lang, A.; Maor, Y.; Eliakim, R.; Ben-Horin, S. (Tel Hashomer/Tel-Aviv)

46 Outcomes of Secondary Self-Expandable Metal Stents versus Surgery after Delayed Initial Palliative Stent Failure in Malignant Colorectal Obstruction Yoon, J.Y.; Park, S.J.; Hong, S.P.; Kim, T.I.; Kim, W.H.; Cheon, J.H. (Seoul)

56 On-Demand Proton Pump Inhibitory Treatment in Overweight/Obese Patients with Gastroesophageal Reflux Disease: Are There Pharmacodynamic Arguments for Using Higher Doses?

Bruley des Varannes, S. (Nantes); Coudsy, B. (Issy-les-Moulineaux); Waechter, S. (Baar); DeLemos, B.; Xiang, J.; LoCoco, J. (Raritan, N.J.); Ducrotté, P. (Rouen)

\section{No. 2}

Editorial

125 Computed Tomography Just after Endoscopy as the Preoperative Examination for Safe Percutaneous Endoscopic Gastrostomy

Adachi, Y.; Akino, K.; Mita, H.; Kikuchi, T.; Endo, T. (Sapporo)

Original Papers

65 Polymorphism of ITGB2 Gene 3'-UTR+145C/A Is Associated with Biliary Atresia Zhao, R.; Song, Z.; Dong, R.; Li, H.; Shen, C.; Zheng, S. (Shanghai)

72 Clinical Impact of Endoscopic Devices for Colorectal Endoscopic Submucosal Dissection

Harada, A.; Gotoda, T.; Fukuzawa, M.; Moriyasu, F. (Tokyo)

79 Association of Gastric Mucosal Injury Severity with Platelet Function and Gastric pH during Low-Dose Aspirin Treatment Nishino, M. (Hamamatsu/Shizuoka); Sugimoto, M.; Uotani, T.; Yamade, M.; Sahara, S.; Ichikawa, H.; Sugimoto, K.; Umemura, K.; Watanabe, H.; Miyajima, H.; Furuta, T. (Hamamatsu)

87 Clinical Usefulness of Endoscopic Palliation in Patients with Biliary Obstruction Caused by Hepatocellular Carcinoma Choi, J.; Shim, J.H.; Park, D.H.; Lee, S.S.; Seo, D.W.; Lee, S.K.; Kim, M.-H.; Kim, K.M.; Lim, Y.-S.; Chung, Y.-H.; Lee, Y.S.; Suh, D.J.; Lee, H.C. (Seoul)

95 Needle Knife Precut Papillotomy and Fistulotomy for Difficult Biliary Cannulation during Endoscopic Retrograde Cholangiopancreatography

Zhang, Q.; Han, B.; Xu, J.; Bao, W.; Tao, J.; Zhang, Y. (Shanghai)

101 Predictive Factors for Development of Chronic Pouchitis after Ileal Pouch-Anal Anastomosis in Ulcerative Colitis Okita, Y.; Araki, T.; Tanaka, K.; Hashimoto, K.; Kondo, S.; Kawamura, M.; Koike, Y.; Otake, K.; Fujikawa, H.; Inoue, M.; Ohi, M.; Inoue, Y.; Uchida, K.; Mohri, Y.; Kusunoki, M. (Tsu)

110 Low-Volume Morning-Only Polyethylene Glycol with Specially Designed Test Meals versus Standard-Volume Split-Dose Polyethylene Glycol with Standard Diet for Colonoscopy: A Prospective, Randomized Trial

Seo, E.H.; Kim, T.O.; Park, M.J.; Heo, N.Y.; Park, J.; Yang, S.Y. (Busan)

119 Constipation in Patients with Thiamine Deficiency after Roux-en-Y Gastric Bypass Surgery Shah, H.N.; Bal, B.S.; Finelli, F.C.; Koch, T.R. (Washington, D.C.)

128 Clinical Features and Comprehensive Diagnosis of Autoimmune Pancreatitis in China Wu, L.; Li, W.; Huang, X.; Wang, Z. (Beijing)

\section{KARGER}

E-Mail karger@karger.com www.karger.com (c) 2013 S. Karger AG, Basel

Access to full text and tables of contents, including tentative ones for forthcoming issues: www.karger.com/dig_issues 
No. 3

Reviews

135 Delicate Balance of Bleeding and Thrombosis in End-Stage Liver Disease and Liver Transplantation

Saner, F.H. (Essen); Gieseler, R.K. (Essen/Hannover); Akız, H. (Adana);

Canbay, A. (Essen); Görlinger, K. (Essen/Munich)

193 Artificial Nutrition and Intestinal Mucosal Barrier Functionality

Anastasilakis, C.D.; Ioannidis, O.; Gkiomisi, A.I.; Botsios, D. (Thessaloniki)

Meeting Report

153 Digestive Disease Management in Japan: A Report on The 6th Diagnostic Pathology Summer Fest in 2012

Ichikawa, K.; Fujimori, T. (Tochigi); Moriya, T. (Kawasaki); Ochiai, A. (Chiba); Yoshinaga, S.; Kushima, R.; Nagahama, R.; Ohkura, Y. (Tokyo); Tanaka, S. (Hiroshima); Ajioka, Y. (Niigata); Hirata, I. (Aichi); Tanaka, M. (Hirosaki); Hoshihara, Y. (Tokyo); Kinoshita, Y. (Shimane); Sasano, H. (Sendai); Iwashita, A. (Fukuoka); Tomita, S. (Tochigi); Hirota, S. (Hyogo); Yao, T. (Tokyo); Fujii, S. (Kyoto); Matsuda, T. (Tokyo); Ueno, H. (Saitama); Ishikawa, Y.; Takubo, K. (Tokyo); Fukushima, N. (Tochigi); Sugai, T. (Morioka); Iwafuchi, M. (Niigata); Imura, J. (Toyama); Manabe, T. (Kyoto); Fukayama, M. (Tokyo)

Original Papers

145 Sleep Disturbances and Refractory Gastroesophageal Reflux Disease Symptoms in Patients Receiving Once-Daily Proton Pump Inhibitors and Efficacy of Twice-Daily Rabeprazole Treatment

Fujiwara, Y.; Habu, Y.; Ashida, K. (Osaka); Kusano, M. (Maebashi); Higuchi, K.; Arakawa, T. (Osaka)

161 Long-Term Follow-Up in Patients with Indeterminate Barrett Esophagus

Becker, V.; Bobardt, J.; Ott, R. (Munich); Rösch, T. (Hamburg); Meining, A. (Munich)

165 Argon Plasma Coagulation of Gastric Inlet Patches for the Treatment of Globus Sensation: It Is an Effective Therapy in the Long Term

Klare, P.; Meining, A.; von Delius, S.; Wolf, P.; Konukiewitz, B.; Schmid, R.M.; Bajbouj, M. (Munich)

172 Fibroblast Growth Factor Receptor 1 as a Putative Therapy Target in Colorectal Cancer

Göke, F.; Göke, A.; von Mässenhausen, A.; Franzen, A.; Sharma, R. Kirsten, R.; Böhm, D.; Kristiansen, G. (Bonn); Stenzinger, A. (Heidelberg); Wynes, M.; Hirsch, F.R. (Aurora, Colo.); Weichert, W. (Heidelberg); Heasley, L. (Aurora, Colo.); Buettner, R. (Cologne); Perner, S. (Bonn)

182 Hypoxia Induces the Expression of Transketolase-Like 1 in Human Colorectal Cancer

Bentz, S.; Cee, A. (Zurich); Endlicher, E. (Regensburg); Wojtal, K.A. (Zurich); Naami, A. (Aachen); Pesch, T.; Lang, S. (Zurich); Schubert, P. (Darmstadt); Fried, M.; Weber, A. (Zurich); Coy, J.F. (Darmstadt); Goelder, S. (Augsburg); Knüchel, R. (Aachen); Hausmann, M.; Rogler, G. (Zurich)

192 Erratum
No. 4

Review

258 Clinical Application of Liver Stiffness Measurement Using Transient Elastography: A Surgical Perspective Kim, S.U.; Kim, B.K.; Han, K.-H. (Seoul)

Original Papers

209 Long-Term Efficacy of Pneumatic Dilation and Esophageal Stenting for the Treatment of Achalasia

Qian, L.; Wang, B. (Nanjing/Suzhou); Li, K.; Yu, L.; Ding, J.; Zhang, H.; Ding, X.; Shi, R. (Nanjing)

217 Refractoriness of Intestinal Behçet's Disease with Myelodysplastic Syndrome Involving Trisomy 8 to Medical Therapies - Our Case Experience and Review of the Literature Toyonaga, T. (Hirakata); Nakase, H.; Matsuura, M.; Minami, N.; Yamada, S.; Honzawa, Y. (Kyoto); Hukata, N. (Hirakata); Yoshino, T.; Chiba, T. (Kyoto); Okazaki, K. (Hirakata)

222 Clinical Efficacy of Infliximab in Moderate to Severe Ulcerative Colitis in a Latin American Referral Population

Juliao, F;; Marquez, J.; Aristizabal, N.; Yepes, C.; Zuleta, J. (Medellín); Gisbert, J.P. (Madrid)

229 Pharyngeal Cancer Surveillance Using Narrow Band Imaging during Conventional Upper Gastrointestinal Endoscopy Saito, M. (Sapporo/Muroran); Yamashita, K.; Tanuma, T. (Sapporo); Kaneto, H.; Murakami, K.; Onodera, K.; Shimizu, H.; Sakamoto, H. (Muroran); Hosokawa-Motoya, M.; Arimura, Y.; Shinomura, Y. (Sapporo)

235 Vascular Endothelial Growth Factor Improves Liver Regeneration and Survival after $\mathbf{9 0 \%}$ Hepatectomy in a Rat Model of Diet-Induced Steatosis

Gu, Y.; Sowa, J.-P.; Paul, A.; Gerken, G.; Schlaak, J.F. (Essen)

243 Analysis of the Intestinal Microbiome of a Recovered Clostridium difficile Patient after Fecal Transplantation Broecker, F. (Zurich/Berlin/Potsdam); Kube, M. (Berlin); Klumpp, J.; Schuppler, M.; Biedermann, L. (Zurich); Hecht, J. (Berlin); Hombach, M. (Zurich); Keller, P.M. (Zurich/Jena); Rogler, G. (Zurich); Moelling, K. (Zurich/Berlin/Hamburg)

252 Performance of the Rockall Scoring System in Predicting the Need for Intervention and Outcomes in Patients with Nonvariceal Upper Gastrointestinal Bleeding in a Brazilian Setting: A Prospective Study

Custódio Lima, J.; Garcia Montes, C.; Kibune Nagasako, C.; Soares Ruppert Reis, G.F.; Meirelles dos Santos, J.O.; Guerrazzi, F.; Mesquita, M.A. (Campinas)

266 Lamivudine Treatment Failure Risks in Chronic Hepatitis B Patients with Low Viral Load

Koklu, S. (Ankara); Gulsen, M.T. (Gaziantep); Tuna, Y. (Antalya); Koklu, H.; Yuksel, O.; Yilmaz, B. (Ankara); Karaca, C. (Istanbul); Ataseven, H. (Konya); Guner, R.; Kucukazman, M. (Ankara); Kockar, C. (Isparta); Demir, M. (Hatay); Poyrazoglu, O.K. (Kayseri); Ibis, M.; Purnak, T.; Etgul, S. (Ankara) Alkan, E. (Antalya); Coban, S. (Ankara); Gokturk, S. (Istanbul); Biyik, M. (Konya); Baykal, O. (Isparta); Basar, O. (Antalya); Koklu, N.; Tatar, G.; Simsek, H. (Ankara)

272 Ten-Year Trend of the Cumulative Helicobacter pylori Eradication Rate for the 'Japanese Eradication Strategy' Sasaki, H.; Nagahara, A.; Hojo, M.; Asaoka, D.; Matsumoto, K.; Osada, T.; Watanabe, S. (Tokyo)

279 Acknowledgement to Referees 